\title{
An Investigation on Durability and Ductulity of Concrete using Fly Ash and Fibre Glass
}

\author{
Eedi Divya $^{1}$ | Ch Bhaskara Teja ${ }^{2}$ \\ ${ }^{1}$ PG Student, Dept of Civil Engineering, Vikas College of Engineering and Technology, Vijayawada, India. \\ ${ }^{2}$ Associate Professor, Dept of Civil Engineering, Vikas College of Engineering and Technology, Vijayawada, India.
}

To Cite this Article

Eedi Divya and Ch Bhaskara Teja, "An Investigation on Durability and Ductulity of Concrete using Fly Ash and Fibre Glass”, International Journal for Modern Trends in Science and Technology, Vol. 06, Issue 07, July 2020, pp.:170-174; https://doi.org/10.46501/IJMTST060728

\section{Article Info}

Received on 11-June-2020, Revised on 27-June-2020, Accepted on 18-July-2020, Published on 25-July-2020.

\section{ABSTRACT}

Concrete enterprise is dealing with the environmental impact, via the emission of CO2 while cement manufacturing. Cement partly replaced with pozzolanic waste fabric like fly ash reduces the freeing of CO2. Fly ash is made of thermal energy plants. Due to the usage of glass fibers to standard concrete has a big compressive strength and flexural Strength. This research work deals the look at of different grades (M30, M40) of GFRC by means of partial substitute of cement with fly ash. In keeping with mix proportions, standard sizes of specimens are casted that allows you to locate the durability properties, ductility and flexural power? Durability properties are performed with the aid of checking out the specimens for sulphate and acid assaults. Whereas ductility and flexural energy is received from pressure-pressure curves. And acquired results are as compared to traditional concrete. Its miles been determined from this research is that, ductility, sturdiness and flexural electricity is higher for GFRC than traditional concrete.

Keywords: Glass fiber, fly ash, compressive strength, stress-strain curve, flexural strength.

Copyright (C) 2020 International Journal for Modern Trends in Science and Technology

DOI: https://doi.org/10.46501/IJMTST060728

\section{INTRODUCTION}

Slags OPC 53 grade $\mathrm{S}$ cement is manufactured as per specification laid down by ministry of railways under IRST40: 1985. It is a very finely ground cement with is high C3S content designed to develop high early strength required for manufacture of concrete sleeper for Indian Railway. Cementations materials such as mortars and concretes are utilized for the development of construction material because they are durable, low-cost and have an adequate compressive strength and stiffness for structural use. It cannot be directly used to the structures due to its low ductility and less tensile strength. Fibers prevent micro cracks from widening. The components become ductile and tough due to addition of fibers. Conventional concrete cracks easily. When concrete is reinforced with randomly dispersed fibers, we get favorable behavior for repeated loads. For the fixing of proper reinforcement, it is very difficult for the odd shape of structures, it is not commence in the case of fiber reinforced concrete and the progress of work can be achieved at much faster rate. Generally fly ash has higher impact on the environment because of presence of heavy metals like mercury, cadmium, boron. Our paper deals with effective use of fly ash as a construction material which can be replace up to $40 \%$ by weight of cement.

Due to this the reinforcement or fibers are utilized in the process of concreting. For the thin 
members the fiber reinforced concrete are used to gain the tensile strength. The pozzolanic material having essential with the siliceous and aluminous materials as which reacts with calcium hydroxide in the presence of water at ordinary temperature and liberated in the process of hydration to form compounds as like as possessing cementitious properties. Fly ash is waste material, generated in the thermal power station, when powdered coal is used as fuel. The PPC (Portland Pozzolana Cement) products have the high resistance and with the less heat of hydration to attack the aggressive water than the OPC (Ordinary Portland Cement. In India there is apprehension in the mindsof the user to use the Portland pozzolana cement for structural work.

\section{Methodology}

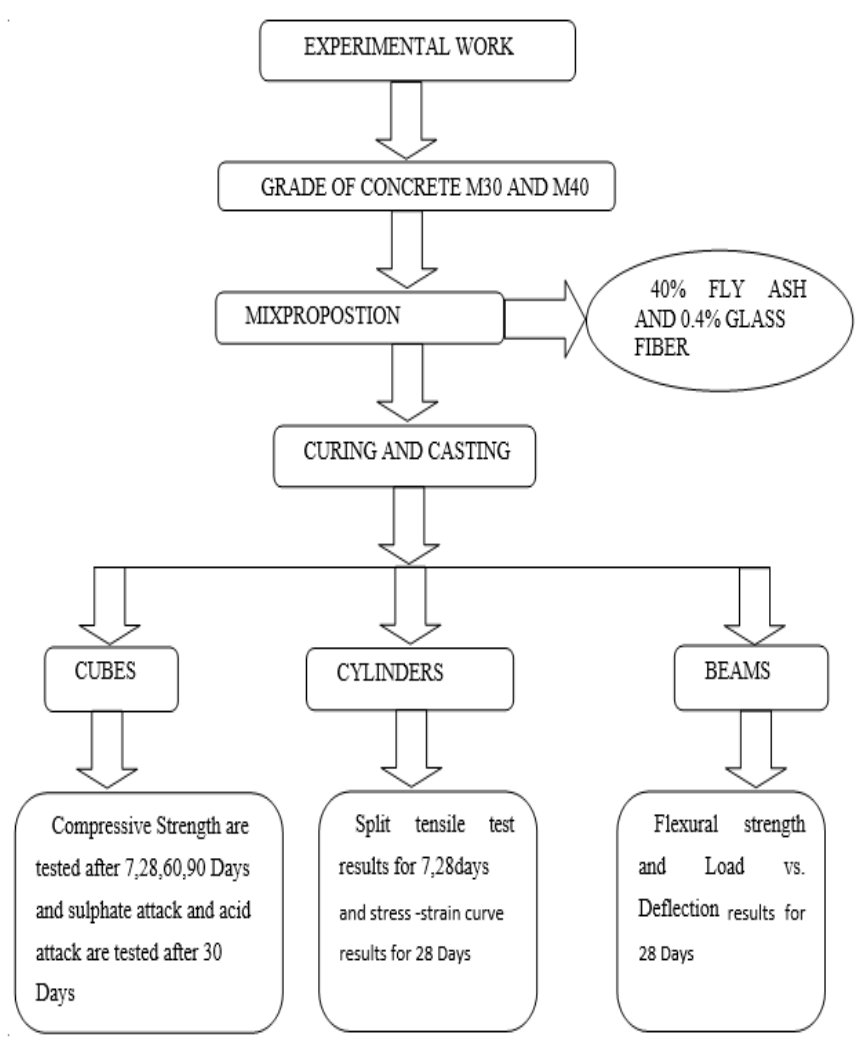

III. MATERIALS USED

Cement: In this experimental work, standard Portland Cement (OPC) of grade-53 was used. Cement is the most important binding material of cement conforming to IS 12699: 1999 is used in this project work.

Fine Aggregate: Locally available river sand belonging to zone II of IS 383-1970 was used for the projectwork.

Coarse Aggregate: The coarse aggregate can be formed by the crushing of granite. And having with the maximum size of $20 \mathrm{~mm}$ and $12.5 \mathrm{mmwas}$ found according to the norms of Indianstandards.

Water: Water is the most important additive to form a molded mix in a concrete. the fresh water available in laboratory are used for concreting mixing and curing both glass fiber reinforced concrete mixes M30 and M40 grades are used in water.

Superplasticizer:Super-plasticizers are high range water reducers that are used to make the mix workable at lower water-to-binder ratios.To increase the workability of the glass fiber reinforced concrete mixes, the high range of water reducing proxy MYK PC-20 has been used in this present work.

Fly Ash:Fly ash is a by-product of combustion of pulverized coal in thermal power plants. It is removed by the dust collection system as a fine particle residue from the combustion of gases before they are discharged into the atmosphere. Fly ash particles are typically spherical, ranging in diameter from less than $1 \mu \mathrm{m}$ up to $150 \mu \mathrm{m}$, the majority being less than $45 \mu \mathrm{m}$. More than 85 percent of most fly ashes comprise of chemical compounds and glasses formed from the elements like silicon, aluminum, iron, calcium, and magnesium.

Glassfiber:Alkali resistance glass fibers are used in project work. Glass fiber is chemically inorganic fiber and obtained from molten glass of Specific composition. Glass fiber is made up of natural materials such that its produces substances of ecologically pure and not harmful to the community. Glass fiber made up from $200-400 \mathrm{~mm}$ individual filaments. It is not possible to mix fibers more than 3\%. Glass fibers have excellent electronic heat and insulation capacities.

Acids:To check the sulphate attack resistance, the specimen is placed in acidic solutions such as $\mathrm{H} 2 \mathrm{SO} 4, \mathrm{MgSO} 4$ with $5 \%$ of concentration in water.

\section{Results AND Discussion}

A. Compressive Strength Test for M30 grade:

\begin{tabular}{|c|c|c|c|c|}
\hline \multirow{2}{*}{$\begin{array}{r}\text { concrete } \\
\text { mix }\end{array}$} & \multicolumn{4}{|c|}{ compressive strength } \\
\cline { 3 - 5 } & 7 days & 28 days & $\begin{array}{l}60 \\
\text { days }\end{array}$ & $\begin{array}{c}90 \\
\text { days }\end{array}$ \\
\hline M30 & 28.22 & 46.70 & 48.81 & 51.9 \\
\hline $\begin{array}{l}\text { M } 30 \text { fly } \\
\text { ash with }\end{array}$ & 30.28 & 51.11 & 54.45 & 56.6 \\
$\begin{array}{l}\text { Glass } \\
\text { Fiber }\end{array}$ & & & & \\
\hline
\end{tabular}


Table 1: Control Mix and Composite Mix for M30 Grade

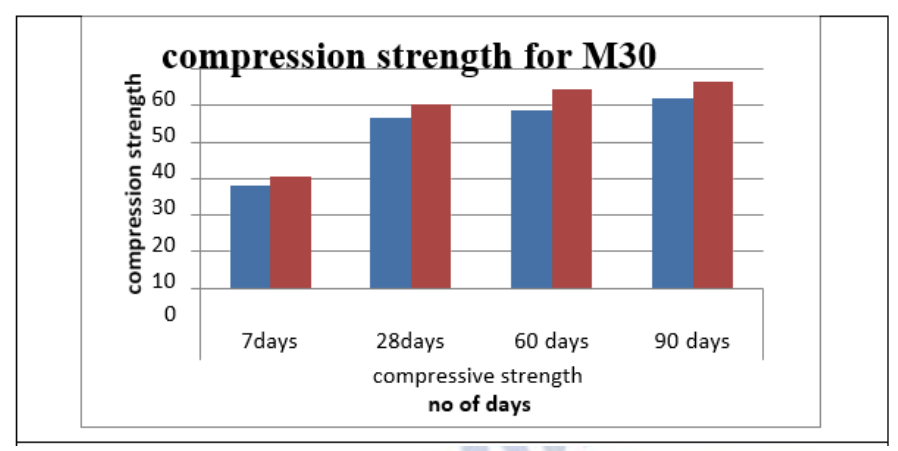

Figure 2: Compressive strength M30 grade plane and fly ash and glass fiber

Compressive Strength Test for M40 grade:

\begin{tabular}{|c|c|c|c|c|}
\hline \multirow{2}{*}{ concrete mix } & \multicolumn{4}{|c|}{ compressive strength } \\
\cline { 2 - 5 } & 7 days & 28 days & 60 days & 90 days \\
\hline M 40 & 36.67 & 54.66 & 55.55 & 60.2 \\
\hline $\begin{array}{c}\text { M 40 fly ash } \\
\text { with Glass } \\
\text { Fiber }\end{array}$ & 40.25 & 56.53 & 60.5 & 65.3 \\
\hline
\end{tabular}

Table 2: Control Mix and Composite Mix for M40 Grade

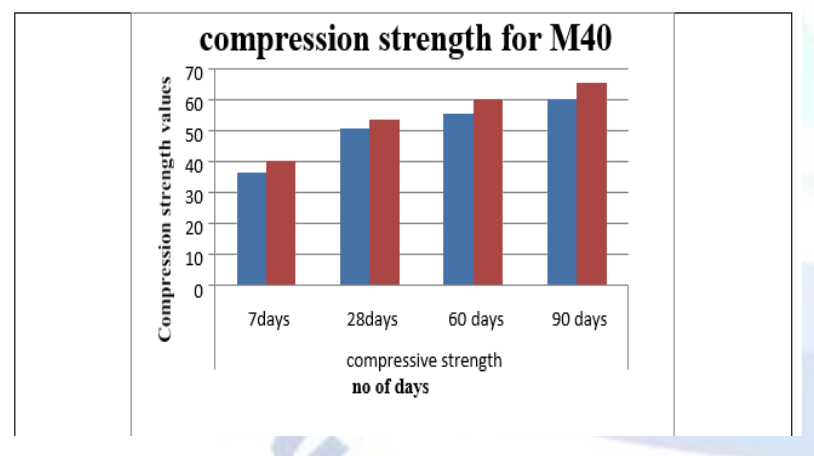

Figure 3: Compressive strength M40 grade plane and fly ash and glass fiber

Split Tensile Strength for M30 grade:

\begin{tabular}{|c|c|c|}
\hline \multirow{2}{*}{ concrete mix } & \multicolumn{2}{|c|}{ Split Tensile strength } \\
\cline { 2 - 3 } & 7 days & 28 days \\
\hline M 30 Plain & 2.82 & 3.25 \\
\hline $\begin{array}{c}\text { M 30 fly ash with Glass } \\
\text { Fiber }\end{array}$ & 3.4 & 3.50 \\
\hline
\end{tabular}

Table 3: Control Mix and Composite Mix for M30 Grade

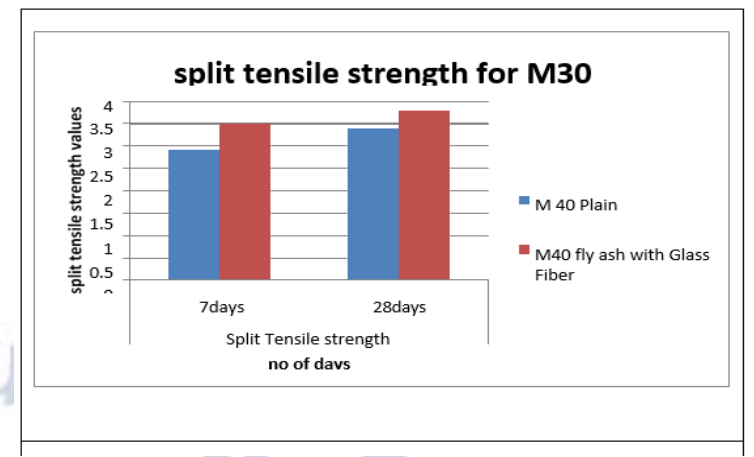

Figure 4: Split strength M30 grade plane and fly ash and glass fiber

Split Tensile Strength for M40 grade:

\begin{tabular}{|l|l|l|}
\hline \multirow{2}{*}{ concrete mix } & \multicolumn{2}{|c|}{ Split Tensile strength } \\
\cline { 2 - 3 } & 7 days & 28days \\
\hline M 40 Plain & 2.9 & 3.40 \\
\hline $\begin{array}{c}\text { M40 fly ash with Glass } \\
\text { Fiber }\end{array}$ & 3.5 & 3.62 \\
\hline
\end{tabular}

Table 4: Control Mix and Composite Mix for M40 Grade

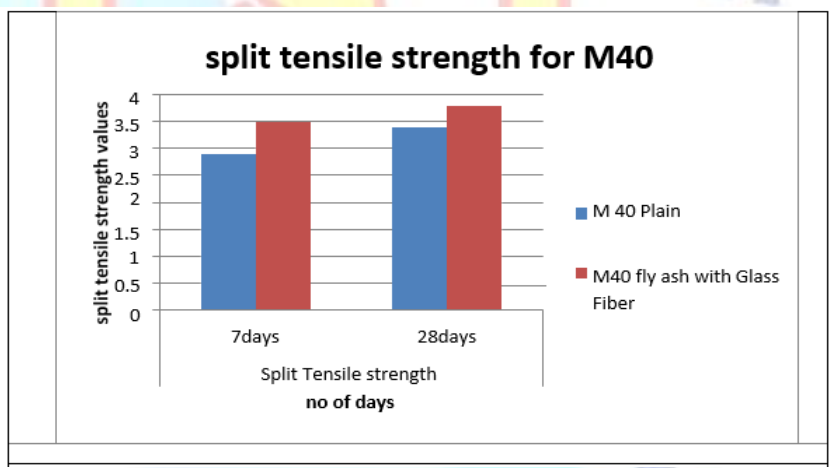

Figure 5: Split Tensile M40 grade plane and fly ash and glass fiber

\section{Stress-Strain Curve on Control Mix:}

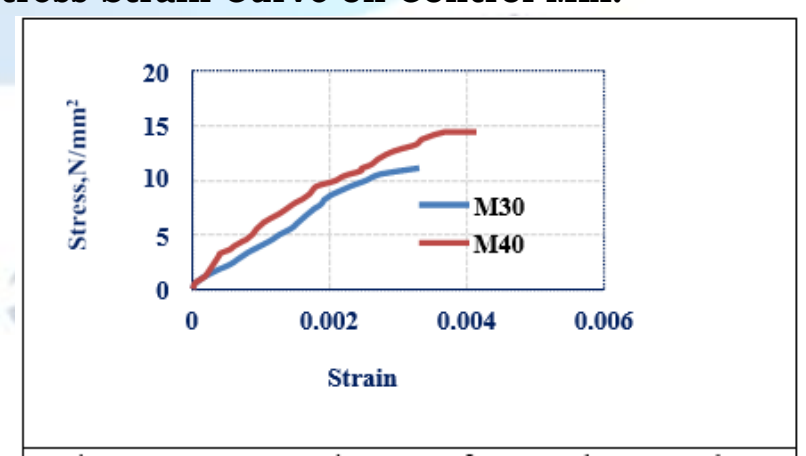

Figure 6: Stress-Strain curve of M30 and M40 grade control mix

Stress-Strain Curve on Composite mix: 


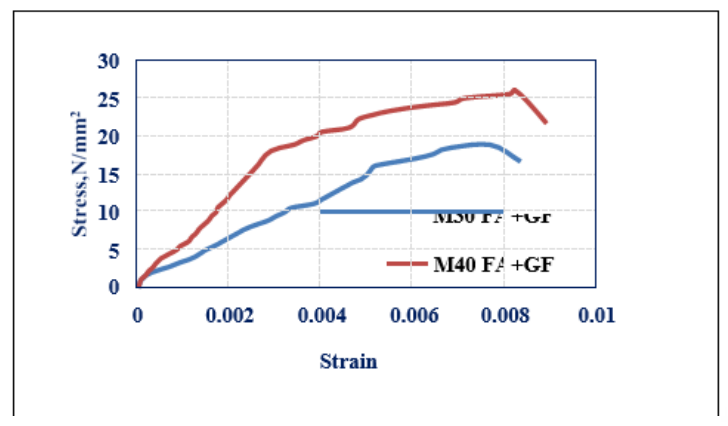

Figure 7: Stress-Strain Curve of M30 and M40 grade composite mix

\section{Flexural Strength Test:}

\section{Composite mix:}

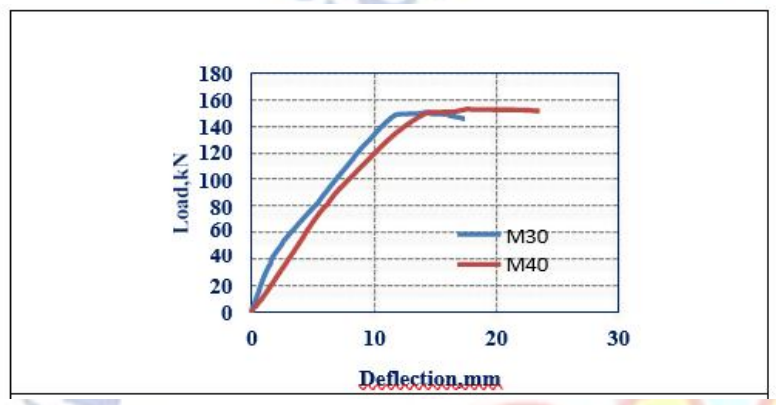

Figure 8: Flexural strength of beam with Composite Control mix: mix M30 and M40 grade of concrete

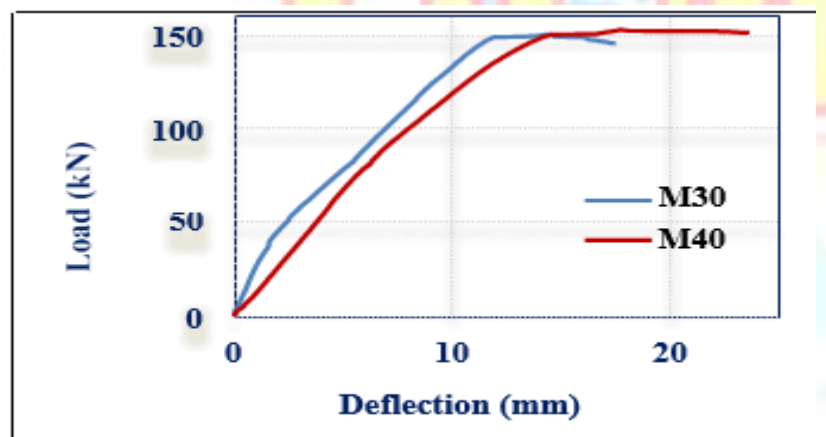

Figure 9: Flexural strength of beam with Control mix M30 and M40 grade of concrete

\section{Durability Studies with H2SO4 AND MgSO4:}

\section{Sulphate attack for M30:}

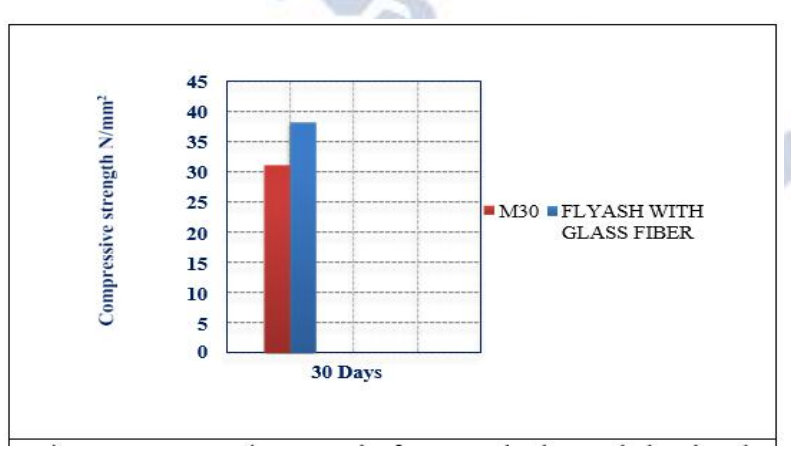

Figure 10: Compressive Strength of M30 Grade plane and Fly ash and Glass fiber with Sulphate Attack

\section{Sulphate attack for M40:}

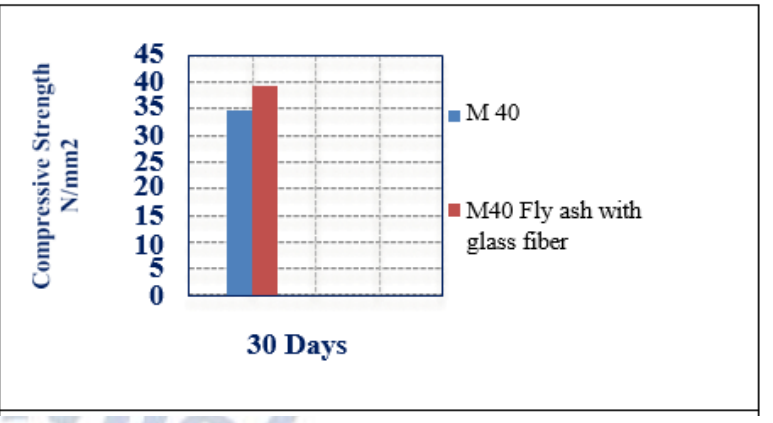

Figure 11: Compressive Strength M40 Grade plane and Fly ash and Glass fiber With Sulphate Attack Acid attack for M30:

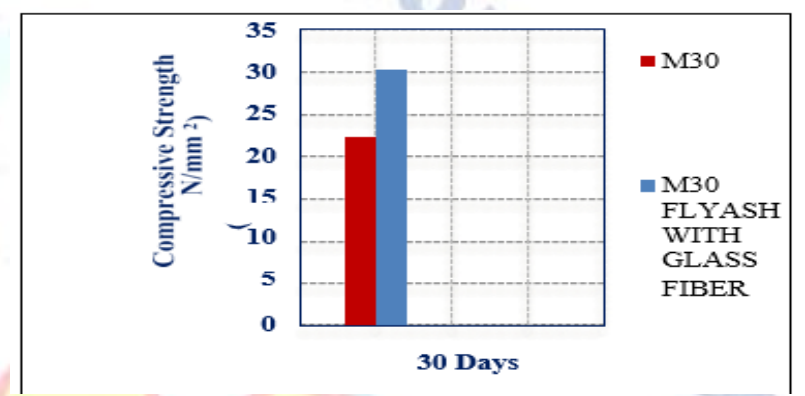

Figure 12: Compressive Strength M30 Grade plane and Fly ash and Glass fiber With Acid Attack

Acid attack for M40:

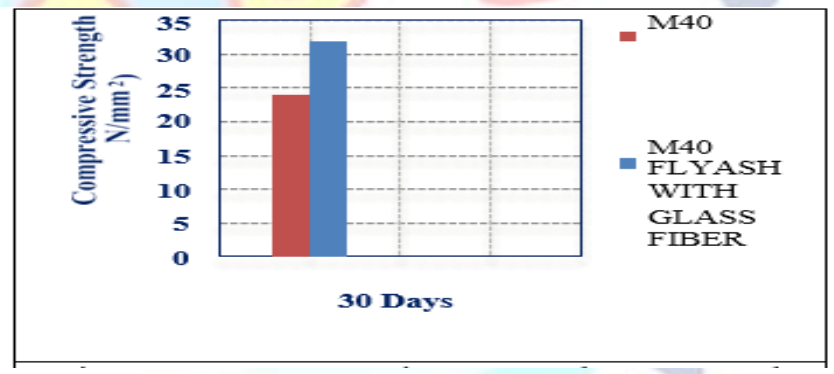

Figure 13: Compressive Strength M40 Grade plane and Fly ash and Glass fiber With Acid Attack

\section{v. Conclusion}

The following conclusions were obtained by the addition of glass fiber and fly ash as the replacement of cement.

1.The addition of glass fiber and fly ash has improved the compressive strength, split tensile strength and flexural strength of concrete.

2. The slump value of the concrete mix by adding Fly ash and Glass fiber is $73 \mathrm{~mm}$.

3. For the mix of Fly ash (40\%), Glass fiber (0.5\%) and Cement (60\%), there obtained a low workability. 
4. The addition of $0.8 \%$ of admixture is used to increase its workability.

5. The compressive and Split tensile strength of M30 and M40 conventional concrete were less when compare to composite concrete.

6. When compared with Composite mix, the stress-strain values of Control mix were high. With the replacement of cement with Fly ash and Glass fiber, the load carrying capacity of beam increases.

7. When the cubes of Composite mix (M30 \& M40) treated with MgSO4, the compressive strength value increase when compared with the cubes of control mix (M30 \& M40) due to Sulphate attack.

8. In case of $\mathrm{H} 2 \mathrm{SO} 4$, the compressive strength for the composite mix of M30 \& M40 was increased when compared with control mix.

9. Flexural Strength for the conventional concrete which is having the ultimate load of $151.7 \mathrm{KN}$ is $24.7 \mathrm{~N} / \mathrm{mm} 2$.

10. The Flexural Strength for the composite concrete which is having the ultimate load of 154.3 $\mathrm{KN}$ is $25.14 \mathrm{~N} / \mathrm{mm} 2$.

\section{REFERENCES}

[1] B. A. V. R. Kumar and J. V. Rao, "Effect of Inclusion of Glass Fibers and Fly ash in Concrete Paver Blocks," Vol. 3,no. 9, 2015, pp. 436-443.

[2] H. S. Rao, S. H. M. Somasekharaiah, and V. G. Ghorpade, "Residual Compressive Strength of Fly Ash based Glass Fiber Reinforced High Performance Concrete Subjected to Acid," International Journal of Engineering Science and Technology, Vol. 4, no. 01, 2012, pp. 71-

[3] K. M. Gopalakrishnan and R. Murugesan, "Flexural behavior of RC Beam, Strength and Durability studies of Concrete made with Recycled Concrete Aggregate, M Sand and Different Mineral Admixtures," Indian J. Geo-Marine Sci., Vol. 45, no. 4, 2016, pp. 556- 565.

[4] K. Venu, R. Reddy, and S. Vijayan, "Glass Fiber Reinforced Concrete with Partial Replacement of Cement with Fly ash," Int. J. Innov. Res. Sci. Peer Rev. Journal, Vol. 5, no. 2, 2016, pp. 2489-2494.

[5] M. Barbuta, R. Bucur, A. A. Serbanoiu, S. Scutarasu, and A. Burlacu, "Combined Effect of Fly Ash and Fibers on Properties of Cement Concrete," Procedia Eng., Vol. 181, 2017, pp. 280-284.

[6] R. M. Rao and S. Rao, "Effect of Glass Fibers on Fly ash Based Concrete," Int. J. Civ. Struct. Eng. Eng., Vol. 1, no. 3, 2010, pp. 606-612.

[7] S. V. Kaithoju and M. A. Jabbar, "Behavior of Hybrid Fiber Reinforced Concrete with Partial Replacement of Cement by Fly Ash in Flexure," no. 2012, 2018, pp. 5115-5121.

[8] R. Bhargavi and B. Pravallika, "Experimental Study on Strength and Durability Properties of Steel Fibers \& Glass Fibers using GGBS based Concrete," Int. J. Sci. Res., Vol. 5, no. 6, 2016, pp. 2296-2300.

[9] V. Jayashree, "Strength Study on Activated Fly Ash," Vol. 9, no. 3, 2018, pp. 36-41. 